\title{
The Influence of Audit and Hospital Council on Financial Statements' Results in Slovenian Hospitals
}

\author{
TATJANA HORVAT \\ University of Primorska, Slovenia \\ tatjana.horvat@fm-kp.si \\ DARKO ČANDER \\ Health Center of dr. Adolf Drolc Maribor, Slovenia \\ cander.darko@gmail.com
}

This study focuses on the connection of frequency of monitoring financial statements by internal auditors and by hospital councils with the efficiency of operations in Slovenian hospitals. The aim of the hospital is not making profit; however, it has to be economical to operate, which means that it must generate a surplus of revenues over expenditures, which is reflected in the annual financial statements. The financial statements are the responsibility of management. Founder of the hospitals is Republic of Slovenia, all the founder's rights and obligations are exercised by the Government of the Republic of Slovenia. In Slovenia there are 26 public hospitals (the population) and they are divided into ten general hospitals, seven specialist hospitals, five psychiatric hospitals, two maternity hospitals and two clinical centres. The State budget and the Health Insurance Institute of Slovenia (HIIs) are the main sources of public financing Slovenian hospitals. Sources of financing hospitals are also evident in annual financial statements of each hospital. In the study, the 25 Slovenian public hospitals (the sample), which mostly represent Slovenian health system, have been analysed. We collected data with the survey questionnaire and from their published financial statements for 2014 . For testing two hypotheses, we used contingency table and ChiSquare test. The results showed that the frequency of internal audits is not connected with the efficiency of operations in Slovenian hospitals, but the frequency of hospital council's supervision is connected with the efficiency of operations. Hospitals with more often monitoring of results in financial statements by hospital councils have surpluses in revenues (making profit). Findings suggest to focus on quality not only on frequency of internal audits and to propose to hospitals with surpluses in expenditures to have more often monitoring by hospital councils. Findings suggest to hospitals to focus on quality of planning revenues and costs. The paper suggests to health policy makers to develop hospital's corporate governance. The effective corporate gover- 
nance in hospitals, with clear responsibilities of managers, auditors and councils, might effects on fiscal stability of the health system and the balance between all hospital's stakeholders.

Key words: internal audit, management, financial statements, income statement, hospitals

https://doi.org/10.26493/1854-4231.14.138-149

\section{Introduction}

In the area of health care the state must constantly worry about its financial balance and sustainability. This study offers evidence about practices of monitoring the financial statements by internal financial auditors and hospital councils in Slovenian hospitals. We decide for this study, because among the four main priorities of the Slovenian Ministry of Health is strengthening public health having regard to its financial balance and sustainability and increasing the responsibilities of directors and councils of public hospitals (Čander 2016).

Slovenian hospitals as public institutions, which will be our object of study, are public health institutions and form part of a network of health services, providing residents to exercise their rights to health care services at the secondary level. Secondary level includes specialist outpatient and inpatient activity and comprising an in-depth diagnosis of the disease or other medical conditions and the implementation of ambulatory rehabilitation as the continuation or complement of Primary Care (Računsko sodišče Republike Slovenije 2014; Čander 2016).

Founder of the hospitals is Republic of Slovenia, all the founder's rights and obligations are exercised by the Government of the Republic of Slovenia. In Slovenia there are 26 public hospitals and they are divided into ten general hospitals, seven specialist hospitals, five psychiatric hospitals, two maternity hospitals and two clinical centres. Clinical Centre Ljubljana and Maribor and Institute of Oncology, Clinic Golnik and Psychiatric Clinic Ljubljana, implement their activity also at the tertiary level, which includes in addition to the general tasks' activities such as scientific research and educational work.

The State budget and the Health Insurance Institute of Slovenia (HIIs) are the main sources of public financing Slovenian hospitals. Sources of financing hospitals are also evident in annual financial statements of each hospital. Evaluation can be made in monetary or non-monetary terms (Milost 2012, 830). The aim of the occupation of the public institution is not making profit, however, it has to 
be economical to operate and to ensure the positive result of efficiency of operations, which means that it must generate a surplus of revenues over expenditures, which is reflected in the financial statements. They are showing the economy of operation (namely from the difference between revenues and expenditures), they are under the responsibility of management and formally monitored by the hospital council and financial internal auditor. We could say, that board of management, board of hospital council and internal auditor, they are all part of aspects of the so-called corporate governance. As developed by the Organisation for Economic Co-operation and Development (OECD) 2001: Corporate governance is about the procedures and processes according to which an organisation is directed and controlled (Tricker 2015, 30). An effective system of corporate governance requires an effective financial reporting system (Baker and Wallage 2000, 173). Authors of study (Joseph et al. 2011) made 12 recent literature review or meta-analysis papers and summarized selected results from recent empirical research papers, reviewed the findings of over 250 studies and confirmed, that board and audit committee issues are in central focus primarily as part of corporate governance focus.

The health sector is facing a major challenge of change and is integrated into 'wedge' progress of scientific medicine, health policy and is faced with restrictions by the payer of public health services on the one hand and the growing needs and wishes of the users of health services on the other hand (Ule 2003, 52; Čander 2016, 2).

In Slovenian hospitals we have two main formal ways of monitoring the financial results of Slovenian health care system, especially by internal audit and supervision by hospital council, which should ensure the positive result of efficiency of operations (surplus of revenues over expenditures in income statement). Namely, management is responsible for the financial statements, so monitoring the financial statements means monitoring the managers how they financially lead the hospital.

The aim of the occupation of the public institution is not making profit, however, it has to be economical to operate, which means that it must generate a surplus of revenues over expenditures, which is reflected in the financial statements. The financial statements are showing the economy of operation (namely from the revenue and expenditure). The financial statements are due to economy of operation monitored by the hospital council board. The hospital council board is composed of representatives of the founder, representatives of the staff and representatives of users and the interested public

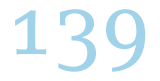


(Article 29 of the Law on Institutions). Management of the hospital organizes and manages the work and operations of the institution, presents and represents the institution and is responsible for the legality of the institution and financial statements. The research among 400 executives in United States states that surprisingly $78 \%$ of that sample admits to sacrificing long-term value in favour of smooth earnings (Graham, Harvey, and Rajgopal 2005, 3). So, we consider that monitoring the financial statements by the hospital councils is very important (Horvat 2014).

The Slovenian Public Finance Act is a formal basis for the financial internal control of financial and accounting operations of public institutions and it defines that internal auditing provides an independent verification of financial operations and controls to the management and to the hospital's council to improve their effectiveness. On this basis, Minister of Finance, issued the Regulation on Guidelines for the Harmonious Functioning of the Public Internal Financial Control. One of the studies concluded that organisations which was invested on effective internal control systems had more improved financial performance compared to those manufacturing firms that had a weak internal control system (Njeri 2014). We have to emphasize that internal auditing in public institutions such hospitals in Slovenia is the formal obligation (Horvat 2014).

Considering the theoretical facts and facts from the law, two main control entities of hospital's results in financial statements are internal financial auditor and the hospital council. In the center of our research we set these two priorities:

- connection of financial internal audit and economy of operations and

- connection of the hospital council and economy of operations.

This not only has a significant impact on the economic efficiency of hospitals, but ultimately affects the whole system of healthcare provision (Pirozek et al. 2015, 1086).

According to our cognition, such research of the health system was not made yet in Slovenia. The mission of our study is to identify the monitoring role on economy of operations (surplus of revenues over expenditures) of internal audit and hospital councils in Slovenia. Internal audit according to their rules is focused on the control of many operations, in the strict sense, we focus just on control over the financial statements. The hospital council has a wide variety of control tasks, because we are put in the forefront the financial statements and economics of hospitals operations, we focus just on one

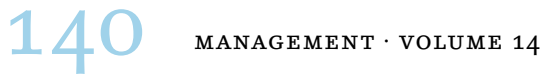


of the supervisory tasks of the hospital council, that is monitoring of financial statements and economy of operations. This are two main limitations of the research.

\section{Methods}

With the research of monitoring the hospital's financial operations and financial statements in the institutions of the Slovenian health system by the internal audit and hospital council, first our purpose is to determine how many internal audits were carried out in Slovenian hospitals during the calendar year 2014 and to verify the connection of frequency (number) of conducted internal audits with the efficiency of operations in the hospitals. Second our purpose is to determine the frequency of monitoring main financial areas in hospital by hospital councils and then to verify the connection of the frequency of monitoring the financial statements by hospital councils with the efficiency of operations.

Therefore, we develop two hypotheses:

нуротнеSIS 1 The frequency of implementation of internal audits of financial operations in general hospitals, specialized hospitals, psychiatric hospitals, maternity hospitals and university medical centres in Slovenia has impact on positive efficiency of operations in those institutions.

нуротнеSIS 2 The frequency of monitoring financial statements by hospitals' councils in general hospitals, specialized hospitals, psychiatric hospitals, maternity hospitals and university medical centres in Slovenia has impact on positive efficiency of operations in those institutions.

Economy of operation is an indicator of data from the registered financial statements for the calendar year 2014 (more precisely from the income statement of revenue and expenditure). In Slovenia, reporting transparency is guaranteed via the Agency of the Republic of Slovenia for Public Legal Records and Services - AJPES (Dolinšek, Tominc, and Lutar-Skerbinjek 2014, 843). Efficiency of operations is measured as an indicator of difference between total revenues and total expenditures of each hospital. If the hospital has a surplus of revenues (making profit), we gave it the value 1. If the hospital had a surplus of expenses (making loss), we gave the hospital the value o. If the revenues are greater than expenses, the indicator of efficiency of operations is positive (hospital creates a so-called profit), otherwise the indicator is negative (hospital creates a loss).

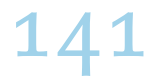


We have assumed that frequent internal audits and hospital councils' supervisions are leading to better final financial results in financial statements, it means that hospital is making surplus of revenues or the so-called profit. We also assumed that hospital could have one to five or more internal audits in a calendar year and never, rare (once a year), often (once in half of the year), very often (quarterly on the year) and regularly (each month) of hospital council' supervisions in a calendar year.

With first hypothesis we want to verify whether the frequency of internal audits of hospital's operations is connected with the positive efficiency of operations respectively the difference between all hospital's revenues and all expenditures, which is a crucial performance indicator of mentioned institutions. Since they are non-profit organizations, we cannot analyse profit, because in health institutions in Slovenia their primary objective is not increasing the capital value of institutions but to invest surplus funds from operations in the development and modernization of health care institutions.

The first hypothesis has been verified with the contingency table and Chi-Square test. We verified the relationship between nominal variables by which we verify whether there is a correlation between the number of internal audits and operational efficiency of Slovenian hospitals. Here we have a categorical variables with more than two values, which in this case is called contingency, data can be represented by the contingency table. The hypothesis was tested at the $5 \%$ level of risk.

Hospitals councils are consisted of members representing the owners (the state) and members representing users (patients), employees and payers (HIIs). Such a heterogeneous structure have not common interests and goals about hospitals operations. Therefore, the second hypothesis assumed that hospital councils do control of the financial statements which ended by surplus of revenues.

The second hypothesis has been verified with the contingency table and Chi-Square test on the relationship between nominal variables, which has been verified a correlation between frequency of control of financial statements done by hospital councils and operational efficiency of Slovenian hospitals. These hypotheses were also tested at the $5 \%$ level of risk.

The basic element was a hospital, which in our case was the subject of the study. We surveyed directors of hospitals (asking them to fulfil the survey or to give to fulfil the survey to their financial directors or assistant of director for financial matters) of all the 26 hospitals in Slovenia. We interviewed the entire population of hospitals

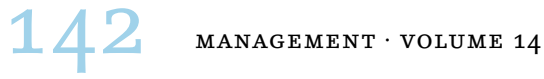


TABLE 1 The Number of Hospitals with the Surplus of Revenues and with the Surplus of Expenditures in 2014

\begin{tabular}{lll}
\hline Surplus of expenses (loss) & Surplus of revenues (profit) & Total \\
\hline 7 & 19 & 26 \\
\hline
\end{tabular}

on public health care system in Slovenia. The survey questionnaire was addressed to all 26 hospitals in Slovenia, for the period from $25 / 04 / 2016$ to $30 / 05 / 2016$. One of the ten general hospitals in that period has not fulfilled the survey, so that the sample survey represented 25 hospitals in Slovenia, which represents $96.15 \%$ of the population. Under the assumption that the sample is representative of the population, findings may be generalized (Arzenšek, Košmrlj, and Trunk Širca 2014, 190). The survey questionnaire contained closed questions with pre-prepared answers yes or no, or claims based on a five-point Likert scale. Reliability of the questionnaire was tested using Cronbach's alpha coefficient, that is in each case amounted to more than 0.7, which indicates that the questionnaire is reliable.

To a questionnaire was answered by 19 females and 6 males. Answered are the following:

- $8 \%$ of the managers (directors),

- $40 \%$ of financial directors and

- $52 \%$ of the assistants of directors for financial matters.

\section{Results}

The research results we reached by theoretical and experience background and statistical hypothesis testing. Hospitals are public institutions and their financial statements are monitored by internal auditors and hospital council. Namely, hospitals are public institutions, which are mostly financed by public money (from state). The research implies the relationship between the monitoring subjects (internal auditors and hospital councils) and efficiency of operations.

First, we collected from the publicly published financial statements of all hospitals the values of efficiency of operations of each hospital. As it has been seen in the table 1, 19 hospitals had surplus in revenues (a profit) and seven hospitals had surplus in expenses (a loss). One hospital with the surplus in revenues was not part of the sample.

Next, with the survey among hospitals we collected the answers from the hospitals on the question, how many internal audits of their financial operations each hospital had in the calendar year 2014.

We made the contingency table (table 2) which shows that one

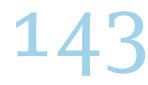


TABLE 2 Contingency Table: Relation of the Number of Internal Audits of Hospital's Financial Operations and the Efficiency of Operations in 2014

\begin{tabular}{lrrr}
\hline Number of internal audits & $(1)$ & $(2)$ & $(3)$ \\
\hline None & 1 & 0 & 1 \\
One & 6 & 11 & 17 \\
Two & 0 & 1 & 1 \\
Three & 0 & 2 & 2 \\
Four & 0 & 3 & 3 \\
Five or more than five & 0 & 1 & 1 \\
\hline Total & 7 & 18 & 25 \\
\hline
\end{tabular}

Notes Column headings are as follows: (1) surplus of expenses, (2) surplus of revenues, (3) total.

TABLE 3 Chi-Square Test

\begin{tabular}{lrrr}
\hline Item & $(1)$ & $(2)$ & $(3)$ \\
\hline Pearson Chi-Square & $5.742^{*}$ & 5 & 0.332 \\
Likelihood ratio & 7.573 & 5 & 0.181 \\
No. of valid cases & 25 & & \\
\hline
\end{tabular}

Notes Column headings are as follows: (1) value, (2) degrees of freedom, (3) asymptotic significance $\left(2\right.$-sided). ${ }^{*} 11$ cells $(91.7 \%)$ have expected count less than 5 . The minimum expected count is 0.28 .

hospital in Slovenia in 2014 did not carry out any internal audit and this hospital had a surplus of expenses, 17 hospitals in the same year carried out one internal audit in year 2014 and eleven of them had surplus of revenues. Seven hospitals had two or more internal audits and they had surplus of revenues.

From the results of Chi-Square Tests (table 3) we saw that there was no statistically significant correlation between the variables. The Chi-Square value is 5.742 and $p=0.332$. The statistical analysis has shown that the number of internal audits is not connected with the efficiency of operations. We can not confirm the first hypothesis. We can affirm that the frequency of internal audits of financial operations in general hospitals, specialized hospitals, psychiatric hospitals, maternity hospitals and university medical centers in Slovenia is not connected with the positive efficiency of operations of those institutions.

In next step, with the survey among hospitals we collected the frequency of monitoring of financial operations in different areas, made by hospital council in 2014. We collected data for these financial areas: financial plans, financial statements, accounting analysis, financial analysis and financial risks. We made frequency table and 
TABle 4 The Frequency Table and Point Analysis of Frequency of Monitoring the Main Financial Operation's Areas by the Hospital Councils in 2014

\begin{tabular}{lrrrrrrr}
\hline Item & $(1)$ & $(2)$ & $(3)$ & $(4)$ & $(5)$ & $(6)$ & $(7)$ \\
\hline Financial plans & 0 & 1 & 6 & 3 & 15 & 107 & 1 \\
Financial statements & 1 & 1 & 7 & 3 & 13 & 101 & 2 \\
Accounting analysis & 1 & 4 & 9 & 2 & 9 & 89 & 3 \\
Financial analysis & 1 & 5 & 9 & 4 & 6 & 84 & 4 \\
Financial risks & 0 & 8 & 7 & 3 & 7 & 84 & 4 \\
\hline
\end{tabular}

Notes Column headings are as follows: (1) never, (2) rarely, (3) often, (4) very often, (5) regularly, (6) points, (7) rang.

TABLE 5 Contingency Table: Relation of the Frequency of Monitoring of Financial Statements by Hospital Council and Surplus in Revenues/Expenses in 2014

\begin{tabular}{lrrr}
\hline Frequency of monitoring & $(1)$ & $(2)$ & $(3)$ \\
\hline Never & 0 & 1 & 1 \\
Rarely & 1 & 0 & 1 \\
Often & 5 & 2 & 7 \\
Very often & 0 & 3 & 3 \\
Regularly & 1 & 12 & 13 \\
\hline Total & 7 & 18 & 25 \\
\hline
\end{tabular}

Notes Column headings are as follows: (1) surplus of expenses, (2) surplus of revenues, (3) total.

point analysis. As seen in table 4, hospital councils are the most often controlling financial plans and financial statements and at least financial risks. In our study we are interested in controlling financial statements.

Next, we made a contingency table (table 5) with the relation of frequency of financial statements monitoring by hospital councils and surpluses in revenues/expenses in 2014. As it follows from table, slightly more than half of hospitals, had regular monitoring of financial statements and 12 of them had surplus in revenues. Three of hospitals had very often monitoring of financial statements and they had surplus in the revenues. Seven hospitals had regular monitoring of financial statements, but five of them had surplus in expenses. The rest two of hospitals, had rare or never monitoring, one was with the surplus of revenues and one with the surplus of expenses.

Based on the data from table 6, the statistical analysis has shown a statistically significant correlation between the variables. We verified whether there is a correlation between the frequency of control of financial statements by the hospital councils and value of surpluses 
TABLE 6 Chi-Square Test

\begin{tabular}{lrrr}
\hline Item & $(1)$ & $(2)$ & $(3)$ \\
\hline Pearson Chi-Square & $13.335^{*}$ & 4 & 0.010 \\
Likelihood ratio & 14.221 & 4 & 0.007 \\
No. of valid cases & 25 & & \\
\hline
\end{tabular}

Notes Column headings are as follows: (1) value, (2) degrees of freedom, (3) asymptotic significance $\left(2\right.$-sided). ${ }^{*} 8$ cells $(80.0 \%)$ have expected count less than 5 . The minimum expected count is 0.28 .

(profit or loss). The Chi-Square value is 13.335 and $p=0.01$. The second hypothesis has been tested at a $5 \%$ level of risk. The significance is lower than 0.05. Monitoring by hospital councils has impact on positive efficiency of operations. We can confirm the second hypothesis and say that the frequency of monitoring of financial statements by hospital councils is connected with the positive result (profit) in hospitals' financials statements.

\section{Discussion}

We have presented and explored two ways of control of financial statements in hospitals. The first method of control is done by internal audit, it is mandatory, but frequency of audits has not an impact on positive efficiency of operations, which is actually consistent with previous studies (Dobija 2015, 124), where the actual practices related to the reviewing of financial policies and alternative accounting treatments are mixed and range from no monitoring to a more substantial overview. To understand the results better, the authors compared them with the primary data gathered in the literature review (Cuvada, Bobek, and Maček 2017, 142). We took into account information related to every assumption made in the beginning of the research and drew the final conclusion about the relation of used variables (Bobek and Maček 2014, 7). We suggest hospitals should give greater emphasize on the quality and not on number of internal audits in hospitals. Slovenian National Guidelines for Internal $\mathrm{Au}-$ diting is implemented by the internal audit as a tool by which the management of the public institution from an independent source gets the assurance that internal controls meet the objectives of the internal control and that the risks are controlled at an acceptable level. Subject of internal auditing are all systems, processes, events and activities of budget user (Edwards 2002, 51). Internal auditing should be a meaningful independent assurance device in operating of the corporate governance 'mosaic' (EEckloo et al. 2004, 1).

The second way of monitoring financial results in hospital is done

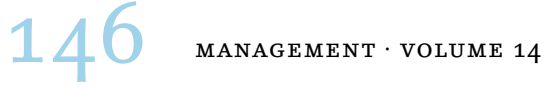


by hospitals councils and they have an impact on positive efficiency of operations. Hospitals whose financial statements are frequently controlled by the hospital council, have surplus of revenues. Hospitals with a negative financial result (loss) should have more frequent monitoring by the hospital councils and we suggest them qualitatively financial planning of revenues and expenses.

Public sector should attempts to adopt private sector governance practices in the belief that this will lead to greater efficiency in achieving outcomes (Roussy 2015, 237). Due to the unique societal position of hospitals - which involves a large diversity of stakeholders - the claim for autonomy of various highly professional groups and the lack of clear business objectives, principles of corporate governance cannot be translated into the hospital sector without specific adjustments. However, irrespective of these contextual differences, corporate governance can provide for a comprehensive 'frame of reference,' to which the hospital sector will have to give its own interpretation (Ministrstvo za finance Republike Slovenije 2003). Namely, over the past two decades, the corporate governance literature in accounting and auditing has grown rapidly (Joseph et al. 2011, 1).

It would be recommended in future to give a greater importance to the key components of corporate governance, which in hospitals already exist but need to be strengthened, that means: greater role of management responsibility for efficiency of operations, greater quality of internal audits and greater responsibility of hospital councils for financial statements.

\section{Conclusion}

Good governance in public hospitals leads to good management, good stewardship of public wealth, good public engagement and, ultimately, better outcomes for citizens and service users (Wadie 2013). As Slovenian directors of public hospitals are also directors of public hospitals for example in New Zealand, they should be aware of their shortcomings in meeting government expectations in respect to financial performance and social responsibility in the hospital (Perkins, Barnett, and Powel 2000, 9).

We believe that the presentation of the influence of internal audit and hospital councils in connection with the positive surpluses in financial statements is useful on micro level for leading and monitoring the hospitals and also on macro level for Slovenian health care system. As a result of multiple developments in health care policy, hospital administrators, policy makers and researchers are increasingly challenged to reflect on the meaning of good hospital gover- 
nance and how they can implement it in the hospital organisations (Eecklo et al. 2004, 1). The effectiveness of the corporate governance of hospitals might affect on the fiscal stability of the health system and, indirectly, health policy for the whole country (Pirozek et al. 2015).

This paper may have implications for improving the overall quality of hospital governance. In the future, we recommend to extend the survey to monitoring other financial areas in hospitals, for example financial plans or financial risks, to the independence of internal financial auditors, and to areas of implementing of managers' responsibilities.

\section{References}

Arzenšek, A., K. Košmrlj, and N. Trunk-Širca. 2014. 'Slovenian Young Researchers' Motivation for Knowledge Transfer.' Higher Education 68 (2): 185-206.

Baker, C. R., and P. Wallage. 2000. 'The Future of Financial Reporting in Europe: Its Role in Corporate Governance.' The International Journal of Accounting 35 (2): 173-87.

Bobek, V., and A. Maček. 2014. 'Negative Effects of the wто: The Case of Automotive Industry in Russia.' International Journal of Diplomacy and Economy 2 (1-2): 71-83.

Cuvada, M. C., V. Bobek, and A. Maček. 2017. 'Motivation Factors for Female Entrepreneurshipin Mexico.' Enterprenual Business and Economics Review 5 (3): 133-48.

Čander, D. 2016. 'Računovodska analiza in analiza dejavnikov finančnih tveganj v slovenskem zdravstvenem sistemu.' Magistrska naloga, Univerza na Primorskem.

Dobija, D. 2015. 'Exploring Audit Committee Practices: Oversight of Financial Reporting and External Auditors In Poland.' Journal of Management and Government 19 (1): 113-43.

Dolinšek, T., P. Tominc, and A. Lutar-Skerbinjek. 2014. 'The Determinants of Internet Financial Reporting in Slovenia.' Online Information Review 38 (7): 842-60.

Edwards, M. 2002. 'Public Sector Governance - Future Issues for Australia.' Australian Journal of Public Administration 61 (2): 51-61.

EEckloo, K., G. V. Herck, C. V. Hulle, and A. Vleugels. 2004. 'From Corporate Governance to Hospital Governance: Authoroty, Transparency and Accountability of Belgian Non-Profit Hospitals' Board and Management.' Health Policy 68 (1): 1-15.

Graham, J. R., C. R. Harvey, and S. Rajgopal. 2005. 'The Economic Implications of Corporate Financial Reporting.' Journal of Accounting and Economics 40 (1-3): 3-73.

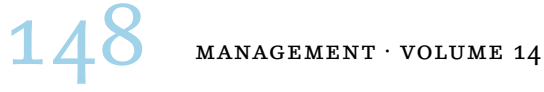


Horvat, T. 2014. Notranja revizija zakonitosti financiranja vzgojno-izobraževalnega zavoda. Ljubljana: Slovenski inštitut za revizijo.

Joseph, V., J. V. Carcello, D. R. Hermanson, and Z. S. Ye. 2011. 'Corporate Governance Research in Accounting and Auditing: Insights, Practice Implications, and Future Research Directions.' Auditing: A Journal of Practice and Theory 30 (3): 1-31.

Milost, F. 2012. 'How to Evaluate Human Capital?' Chinese Business Review 11 (9): 830-38.

Ministrstvo za finance Republike Slovenije. 2003. Usmeritve za državno notranje revidiranje. Ljubljana: Ministrstvo za finance.

Njeri, K. C. 2014. Effect of Internal Controls on the Financial Performance of Manufacturing Firms in Kenya. Nairobi: School of Business, University of Nairobi.

Perkins, R., P. Barnett, and M. Powell. 2000. 'Corporate Governance of Public Health Services: Lessons from New Zealand for the State Sector.' Australian Health Review 23 (1): 9-21.

Pirozek, P., L. Komarkova, O. Leseticky, and T. Hajdikova. 2015. 'Corporate Governance in Czech Hospitals after the Transformation.' Health Policy 119 (8): 1086-95.

Računsko sodišče Republike Slovenije. 2014. 'Revizijsko poročilo: Računovodski izkazi in pravilnost poslovanja Splošne Bolnišnice Izola.' Računsko sodišče Republike slovenije, Ljubljana.

Roussy, M. 2015. 'Welcome to the Day-to-Day of Internal Auditors: How Do They Cope with Conflicts?' Auditing: A Journal of Practice and Theory 34 (2): 237-64.

Tricker, R. I. 2015. Corporate Governance: Principles, Policies and Practies. London: Oxford University Press.

Ule, M. 2003. Spregledana razmerja o družbenih vidikih sodobne medicine. Maribor: Aristej.

Wadie, R. 2013. Corporate Governance in the Public Sector: It's Time! Dubai: Deloitte Middle East. 